\title{
Southern Cross University
}

\section{Adele Wessell}

\section{We are what we grow: reading a tastescape as a text of cultural history}

\begin{abstract}
:
Landscapes provide a layered, textured historical record of cultural change inscribed with meanings that can be harvested in the making of cultural histories. This paper explores the possibility of reading the landscape as a gastronomic text that records cultural dynamics and change over time. What food we eat, and why we eat the food the way we do, shapes the landscape. Eating in this sense is also an agricultural act; the landscape is shaped by consumption and production. Influenced by a number of scholars with an environmental interest (Berry 1990, Petrini 2001), my attention in this article is directed towards the impact of changing tastes on land in Koonorigan, Northern New South Wales, Australia. My home provides a starting point for exploring the possibilities of reading the landscape as a 'tastescape' and the insights this offered that could be considered for other places, different times. A tastescape, moreover, is transnational; a landscape created by tastes not necessarily conditioned by the location but linked elsewhere, to other cultures, ideas and histories that act to construct places. Eating is an agricultural act that brings together these interconnections inscribed on the landscape. The intention is to extend Brillat-Savarin's aphorism to the foodsheds from which meals are drawn: 'Tell me what you grow; I will tell you who you are'.
\end{abstract}

\section{Biographical note:}

Adele Wessell is a historian at Southern Cross University. She is also an Associate Fellow at the National Museum of Australia where she recently undertook a project on the relationship between cooking literature and agriculture, collaborating with Alison Wishart on a paper for ReCollections about the cooking teacher, Flora Pell (2010). Her interests have turned to the use of landscape as a historical text for changes in food history and food as communication, writing 'Faith-based homespace: Decoding good taste in a monastery' with Andrew Jones in Food and Communication: Communication as Food (edited by Janet Cramer). She co-convenes the Australasian Food Studies Network and is co-editor of the 'Pig' themed issue of M/C Journal (October 2010 http://journal.media-culture.org.au) (both with Donna Lee Brien).

\section{Keywords:}

Landscape - tastescape - rural - agriculture - history 


\section{Introduction: reading a landscape}

Many things are edible, but what counts as food is narrated into being. Food is talked about, legislated, promoted, advertised, grown, picked, packaged, sold and preparedalthough it may appear 'natural'. At each step, between production, distribution, preparation and consumption, the meanings of the food change as well as how it looks. Industrialisation and urbanisation have so lengthened the food chain that even people living in rural areas are increasingly uneducated about the origins of their repasts and the pasts of the land they live on. In 2008, I agreed to work on an oral history project interviewing dairy farmers as an opportunity to find out more about my home and the lifestyle of the people who lived there. The iconic Norco butter churn into which the stories were placed under the guidance of international sound sculptor, Colin Black, was itself part of a larger project of redeveloping the Wilson River in Lismore. The Butter Churn sculpture is an artistic component of the Wilsons River Experience Walk and acknowledges Lismore's historic connection to the dairy industry (Wessell 2008). The churn was used between 1962 and 1998, producing six to eight tons of butter everyday from cream collected throughout the north coast. Traces of that past survive on the landscape although the industry no longer provides the common experience or other ties that binds communities together. I read this landscape not as a farmer, but as a consumer and beneficiary of the break-up of dairies into hobby farms.

The notion of a text draws our attention to reading as well as authorship. Extending this idea to the landscape highlights the importance of reading its meanings from consumers as well as producers and broadening the process of agriculture to include eating. The arguments to start our food stories from the land have been critical and persuasive (exemplified by work of the Slow Food movement 2005 and Michael Pollan 2006) but this needs to incorporate the tastes and consumption of consumers which impact on the food that is produced and shapes the environment (Holloway et al. 2007). This is in terms of what food we eat, why we eat the food the way we do, and how shapes the landscape. Reading the landscape as a gastronomic text foregrounds the relationship between humans and their environment and the record of cultural values and practices inscribed in the food choices we make at each meal.

In the 'Pleasures of Eating' Wendell Berry advocates reclaiming responsibility for one's own part in the food economy.

Eating ends the annual drama of the food economy that begins with planting and birth. Most eaters, however, are no longer aware that this is true. They think of food as an agricultural product, perhaps, but they do not think of themselves as participants in agriculture. They think of themselves are 'consumers'. If they think beyond that, they recognise that they are passive consumers (1990: 145).

Eaters, Berry argues, should understand that eating takes place inescapably in the world, that is inescapably an agricultural act, and how we eat determines, to a considerable extent, how the world is used. We are participants in agriculture who have an important role to play in the development of what Pasi Falk calls a tastescape (1994: 68). People need food to survive, but their tastes are conditioned by cultural 
and historical factors; we transform environments to produce the food we recognize, the foods we want to eat or can sell.

Landscapes are a product of culture, a symbolic expression that is time/space specific, as Roland Barthes suggests, 'the cultural sign of Nature' (1988: 68). A tastescape links time and space, production with consumption, in the same discursive formation. What food we eat, as well as how it is grown, can thus be read in the landscape. Taste brings together these interconnections inscribed on the landscape. A tastescape integrates these two senses: the pattern of landforms, plants, human structures that we 'read' in a country; and the experiences, imagining, beliefs and ideas that we bring to our reading. Taste can imply individual choice, but tastes are also historical. The role played by consumer needs and tastes in shaping the land is also cultural and social, rather than individual.

W. G. Hoskins stimulated the study of landscape as a historical record in The Making of the English Landscape (1955). Speaking of his own country, Hoskins suggested 'The English landscape itself, to those who know how to read it aright, is the best historical record we possess' (14). The making of landscapes could be represented chronologically in terms of origins, sources of influence to expose the characteristics of a society in the past and to reveal change and continuity. In the discipline of history the study of landscapes represented a new subject of enquiry with alternative archives and an emphasis on the ordinary, a focus on detail and on locality which engaged scholars with different methodologies and research tools (like good walking shoes and a compass). Emphasis in landscape analysis on viewing and interpreting the historical record echoes in many ways the contemporary concern to read history as a text whose meanings are made by the audience and not laid down wholly by the past.

In a Barthian sense, the author of such texts is the person navigating the space of the landscape, the choices they make and their own aesthetic bias and knowledge or tastes, which shape their investigation and understanding. As cultural products, it is important to keep in mind the way that history and the landscape are read in ways that mediate between the object of interest and our own experiences. How people perceive landscape, as those who read (and write) history, do not focus on the same things in the texts before them. Instead, they draw different ideas and conclusions as they read in ways related to their own experience and expectations. In this way, landscapes provide a layered, textured historical record, and are open to a range of readings. My own preoccupation is with food. As I read the narrative of a landscape, the stories of food related to that location come into view.

Food provides a link between economy, society, appetite and pleasure. It calls our attention to Barry Commoner's first 'law of ecology', that 'everything is connected to everything else' (1971). In the act of eating we bring the natural world into ourselves; our bodies, our insides, depend upon and are nourished by the substances from outside that we take within us. As Amy Trubek suggests, 'Eating ... is the process of bringing the natural world into the human domain' (2005: 260). As we eat, it is well worth considering the alternative; that eating is also the process of bringing the human domain to bear on the natural world. 
While environmental history has been concerned with the relationship between people and food, the focus has largely been on food production. The analysis is frequently limited to cultivation practices, soil, technologies and so on that seek to explain historical change at the point of production (Mink 2009: 313). To fully comprehend food's place in environmental history, however, Nicolaas Mink argues that we must begin in the belly, extending the narrative to those who work and live on the land but also those people hundreds of miles away who sustain themselves from the same land (312-322). As Mink puts it, 'food, at least at the beginning of its journey to the stomach, represents the quintessential embodiment of that enormously complex idea we call nature' (312). Both landscape and food, then, can be read as cultural signs of nature. My desire is to put them together to bring the production of our food back onto the ground. Changing trends in the food industry are rarely considered from the nexus between production and consumption. The massive increase in the consumption of chicken, pork and lamb in Australia, the shift from mutton to lamb, the encouragement to eat three serves of seafood a week, regardless of its impact on the environment, tell a very different story from the ground up.

\section{A rural tastescape}

Reading a tastescape brings layers of time and tastes into present view. Some landscapes tell us more about ourselves than other landscapes, as Geoff Park reminds us, but even these are frequently marginalized in the histories we produce (1995: 15). Rural landscapes integrate historical, ethnographic, architectural and agricultural information about food and the cultural dynamics of the choices we make over time, but scholars confront the challenge of defining rural.

Attempts by academics to define and delimit rural areas and rural societies have always run into problems, sometimes because the distinctions they have drawn have been rather arbitrary, sometimes because they have over-emphasised the differences between city and country, and sometimes because they have under-emphasised the diversity of the countryside (my italics, Woods cited in Gorman-Murray, Darian-Smith, Gibson 2009: 37).

The rural is thus neglected in recent historical discourse, or appears only in local histories. As a consequence, according to Davison and Brodie, we are 'disconnected from an understanding of the longer course of Australian rural history' (Davison and Brodie, cited in Gorman-Murray, Darian-Smith \& Gibson, 2009: 37). The dense networks that connect people who live and work on farming land and those who sustain themselves from the same land, hundreds or thousands of miles away, are therefore hidden. The interlocking chains binding producers and consumers are much clearer when the historical narrative is reoriented to place specific locations in the centre of the story. Such an approach provides a valuable lens to re-examine how food is used and constructed to organise people's lives.

This approach is consistent with the reconsideration of culture inspired by cultural studies theorists to draw attention to the ways in which meanings and values are made concrete through social organisation and social practices on the ground (Hall 1976, 
Geertz 1977). Such practices are socially, spatially and historically specific.

The stories woven around food through individual narratives, inferred from the places themselves and their stories in time, and the wider discourses of food with which they are associated, provide access to the complex intermeshing of production and consumption, public and private. Although food sometimes escapes serious scholarly attention because it is so mundane and ordinary (Lupton 1996), food is profoundly unique in affecting the relations between our personal lives, the integrity of our environment and the practices, policies and institutions central to governance and regulation of the food industry. It touches our intimate and physical environment.

Bearing that in mind, this work is placed in the physical world of my own home and the reading is of narratives experienced and consumed in my every day life. While the stories of Koonorigan are specific to the location, the possibility emerges for other places to be read with different voices and points of entry.

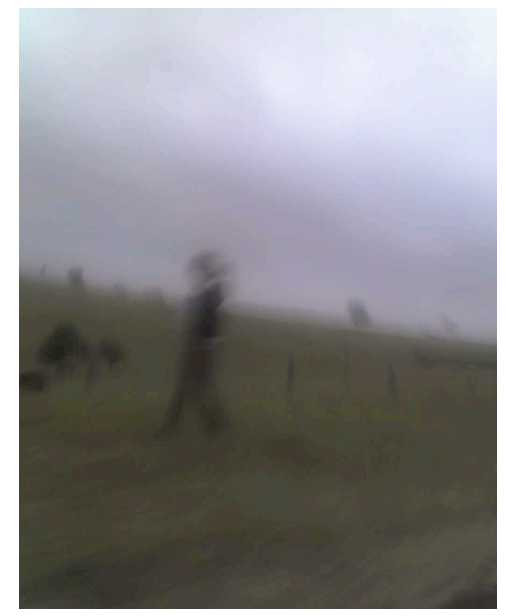

Fig 1. Koonorigan, author's personal collection

\section{The home of my gastronomic landscape}

Food has been central to a number of the social movements that gained momentum in the $1960 \mathrm{~s}$ and that have become increasingly mainstream, including the environmental movement and feminism as well as alternative food movements such as vegetarianism. The north coast of New South Wales has been a focus of counterculture movements in Australia, at least since the Aquarius Festival in 1973, which attracted new settlers to the area to build their own homes, farm organically and practice self-sufficiency (Wilson 2003). Awareness of the politics of food is considerably high on the north coast. Lismore, with a population of around 30,000, is home of the first organic farmer's market in Australia (opened in 1999) and a vegan restaurant and ashram, 20,000 Cows, which was established thirty years ago as a way of providing food that has a philosophy behind it. There is a strong local food movement and a consumer can drink local wine, tea, coffee and beer, eat a large number of vegetables, fruits, tofu and meat from pigs, cows and chickens slaughtered within a 30 kilometre radius. This is not such a clear departure, however, from the lifestyles of rural families living in the area before the 1970s, who grew many of the 
vegetables they needed and slaughtered their own animals for the table. While they may have been more restricted in their movements in and out of town, by income as well as transport and farm responsibilities, and may have had very different reasons for building and relying on their local community, the end result is in fact similar, despite the differences in underlying values.

The Aquarius festival, however, marked an irrevocable change to the dairying community of Nimbin where it was held. Its success was, in part, conditioned by the downturn in the dairy industry, which made it a viable place to host the event and for the new settlers to stay on and establish the first intentional communities (see Gibson 2002, Wilson 2003, Turvey 2006). The imagery evoked by the label 'rainbow region' calls to mind the hippies that have shaped the local communities as well as the Rainbow serpent of the Aboriginal buderam (creation story).

The name is also a reminder of HMS Rainbow, the frigate Captain Henry Rous used to explore the northern rivers of New South Wales in 1828. Feeling the full impact of a prolonged drought in the 1820 s, Rous was commissioned to find suitable new fertile lands for settlement. From the outset the north coast, whose river system Rous explored, was intended for food production although the timber industry initially dominated the local economy. Not knowing how to live off the land, parties of explorers and overlanders travelled with packhorses and bullocks pulling heavy wagons of supplies. The first significant changes to the land made since colonisation were thus from stray cattle, escaping from travelling herds or pastoral holdings.

The New South Wales north coast itself, within which Koonorigan sits, is a narrow coastal plain enclosed by the Great Dividing Range and extending hundreds of kilometres from the Manning Valley in the south to the Queensland border. Koonorigan lies between the Richmond and Tweed valleys, on a plateau of rich volcanic soil, its folds and ridges forming part of the shield of Mount Warning/ Wollumbin, thirteen kilometres from Nimbin. It rises from the low lands of Goolmangar, 'where the cows come first' following a steep ascent to the main ridge which leads to the Nightcap Range, the watershed of the Richmond-Tweed River systems.

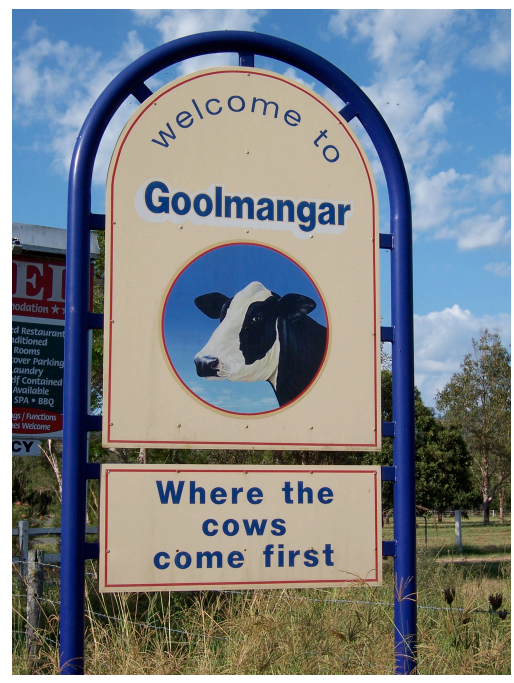

Fig 2. 'Welcome to Goolmangar, Where the cows come first', Lismore City Council sign, Nimbin Rd. 
Koonorigan is a Bundjalung word, a place with many water springs, evoking its past as a sub-tropical rainforest. The summer rains were heavy and the winters were mild. In the late $19^{\text {th }}$ century it was called Burnt Cedar. The country was dimly lit with a thick understorey of ferns and vines broken up with patches of lush grassland, thickly forested with abundant animal and bird life. The creeks teemed with fish. Berries, seeds and fruits flourished. The ridges abounded with pademelon (a small marsupial found in the area), bandicoots, oppossums, snakes, lizards, grubs and brush turkeys, while the open country was plentifully supplied with kangaroos and wallabies. I haven't tasted any of them.

The English had left behind a land of forests, with changing seasons and a climate that supported permanent agriculture; it was relatively cool and damp. Few of them were farmers. The salient features of their own time and place were rural exodus coupled with an almost unimaginable rate of urban growth. They ate more meat than their neighbours and this love of meat helped to shape the eating habits and primary industries of the Australian colonists. Fresh fruit and vegetables supplemented a diet largely based on cereals, tubers, and dried beans, and the varieties of fruits and vegetables were essentially limited to local produce - the kitchen calendar followed the garden calendar (Burnett 1989).

By the time of white settlement in the north coast, the most significant aspect of the world economy was the clearing and cultivation of new land in order to provide the European market with food. In Australia, important developments in the food industry, above all, in preservation and refrigeration and decreased transit times marked the $19^{\text {th }}$ century and shaped both the landscape and eating habits. The influx of dairy farmers from the south during the 1870s was another factor in the upsurge of the industry in the local area. The North Coast Fresh Food and Cold Storage Cooperative Pty Ltd, which later became Norco, built its first butter factory at Byron Bay in 1894. Only a few months after the butter factory began operations, the railway line connecting Lismore, Bangalow, Byron Bay, Mullumbimby and Murwillumbah opened, giving dairy farmers in the area direct access to markets and the port facilities at Byron Bay. As early as 1897, Richmond River butter was exported to the British market. While the area attracted timber getters who felled the teak, rosewood, cudgeri, longjack, blue fig, pine, beech and ironbark forests for cash, it was dairy farmers who largely cleared the 'Big Scrub', creating a landscape in the interests of food production.

The Robertson Land Act of 1861 (NSW) opened up this rich area to free selection. Early attempts at agriculture included sugar, maize and the pasturing of the first dairy cattle that dominated the area of Koonorigan. Colonists would have also used kangaroos, wallabies, possums and fish to supplement their food supplies. The kitchen garden had expanded. By the middle of the $19^{\text {th }}$ century the growing needs of the European food markets, as a result of population growth, industrialisation and urbanization, revealed the basic incapacity of European agriculture to fulfil them. The role of colonial economies became increasingly important and their land resources were seen as inexhaustible as the environment was diverted to farmland and export crops. The landscape created in the interests of European food production has become 
so naturalised that the invasive foreign crops and animals now appear commonplace, and nostalgia for the dairy days normalises this history as communal.

The growth of the dairy industry was largely dependent on the British market so that local and international tastes have a reciprocal relationship in the making of this place. Food and globalization are inseparable. David Bell has coined the term 'transnational rural' to highlight the way the rural can be imagined locally.

Food markets were the first to become globally integrated linking distant areas and cultures of the world. In no other area have the interactions between global exchange and local cultural practices been as discernable as in changing food cultures. Food consumption plays a crucial role for the construction of local and national identities and the changing self-understanding of social groups, migrants and ethnic communities (Bell 2006: 149).

The gastronomic landscape, therefore, is a transnational one; created by tastes not internal to their location but linked elsewhere, to other cultures, ideas and histories that act to construct places. Dairy production in Koonorigan was primarily for export, but, like the plantations of coffee and macadamias that have replaced it, link the village to cultures and markets elsewhere in the world. Dunoon, ten kilometers to the east, is now the macadamia 'capital' of the world, having only recently won the title back from Hawaii when growers achieved success with the native bush nut that Hawaiians had adopted and genetically modified. The uninterrupted rows and rows of macca trees may appear natural in an area where they were native, but the plantations have only been established on the north coast since the 1970s. People need food to survive, but what is grown as that food is dictated by other factors that underpin the transformation of the environment and then impact on the social organization of a community. Society and economics provide food values that create surpluses, control access and distribution.

Agriculture was the driving force of the rural economy and also a pervasive influence in the organization of society and culture in Koonorigan. Before they milked, farmers left breakfast on the table for their children to get themselves off to school, sometimes conveyed by the Cream Carrier. Afternoon tea was also left out for the kids who weren't helping to eat after school, while the farmers milked again. In between they built and repaired fences, baked cakes and tended to commercial vegetable crops. Cows having to be milked twice a day, every day, meant that dairy farmers didn't go on holidays or have Christmas Day off. Having a local hall and branch of the Country Women's Association was therefore important to provide some social outlet for people who could never be too far away from home. For 365 days of the year they milked and when there was no electricity, they milked by hand. As they sold the cream for butter, they raised pigs to drink the milk and grew pumpkins for pig food. Once a month the cattle would be walked up the cutting to be dipped in arsenic solution for ticks. In this way, the production of food in the landscape determined the shape of daily life every day.

Dairy farmers depended on their neighbors and the mutual aid they provided for each other-as well as the integration of work and social lives - contributed to creating a 
resilient network of interdependence among neighbouring farm families. Such interdependence acted as a safety net during illness or absences and provided the basis for successful subsistence. Until the 1970s, the dominant organization of dairy farmers was a co-operative, although by this time, this was declining, as dairy farming had been for some years before that. From the 1970s, the industry was shaken by the deregulation of agricultural industries, environmental and climatic impacts, changing consumer demands and global markets. At the same time, neither income nor labour conditions could necessarily compensate for such changes.

Improvements in working conditions elsewhere in Australia were not passed on and made hired labour in dairying less attractive to employees. The industry was consequently largely dependent on family labour. A 1950 report paints an image of the small-scale dairy farming typical of Koonorigan:

The process of milking and cleaning up the sheds and utensils, properly carried out, absorbs so much time that unless the family does this work the farmer has little time for other jobs on the farm. This is particularly so on small farms, where the number of cows kept does not warrant the use of milking machines (cited in Wadham \& Wood 1950: 186-87).

The average age of dairy farmers on the north coast of NSW in 1960 was 55, and many were significantly older. The industry was largely made up of small family owned farms with less than 60 or 70 cows, mostly producing cream for the manufacture of butter and cheese. Quotas on margarine and the ban from adding food colouring to disguise the white spread or blending it with butter were intended to protect the industry, but these were met with serious complaints from consumers. ${ }^{2}$ Domestic market sales have only just stabilised in the past two decades with the introduction of butter and vegetable oil-based dairy blends that are easier to spread and lower in saturated fat, after a sustained decline through the 1970s and 1980s (Dairying Australia). When the UK joined the European Economic Community in 1973, and imports from Australia virtually ceased, many of the small NSW farms were no longer viable. In Koonorigan, where narrow roads and lanes are also a hindrance to milk tankers, the increasing production of liquid milk presented other limits. Some diverted their dairy farms to other forms of agriculture - most notably the production of vegetables and beef and to new enterprises such as macadamias from the 1970s, and to coffee and plantation forests since the 1980s. Some sold to neighbouring farmers, others to hobby farmers or speculators. Successful farmers expanded their holdings, and introduced or developed their levels of mechanization.

Between 1961 and 2001, the number of Australian farms almost halved, and the size of them grew (Australian Bureau of Agriculture and Resource Economics 2002). The dairy herd increased from an average of 71 in 1970 to 263 thirty years later. Today, the industry nationally produces $83 \%$ more milk than 15 years ago, with a $92 \%$ larger herd and 37\% fewer dairies (Australian Bureau of Statistics, 2004). Life on the farm changed too. There was less to clean when the farms became more mechanised, buying butter (instead of making it) became more common among farmers, and the use of milking machines expanded, all changing the role the whole family played on the farm. As farms became larger, regulation also got tighter, articulated in the Dairy 
Industry Act (1970), which established the Dairy Industry Authority. Bulk milk collection became compulsory, dairies had to be registered and refrigerated holding tanks were introduced.

Alma Graham was one of the farmers who turned to beef production, although she continues to prefer dairy cows. Alma grew up on a dairy farm at Myocum near Byron Bay. When she married, Alma moved to Koonorigan to work on her own dairy farm.

I used to love them... and when we were milking the cows got to love me too. They'd stand there in front of my bail and they'd look at Stew and they'd say don't you let him milk me and they'd stand queued up at my bail so as I'd milk them. Oh they were beautiful and I'd rub them and talk to them and Stew'd say, 'come on get in here'. Know every cow. There'd be 80 and I'd know every cow ... You looked after them. Every little calf you loved them. It was special. Because you realised what that mother was going through. Sometimes you go and you'd see that poor old mother just jump straight over the fence to try and get to her ... try to get to her little baby. I supposed I loved them too much. I did love them ... I couldn't go back to it. I still love the animals (2008).

A collection of such stories is embedded in the landscape, available as fragments or traces of this past. As these are connected within a narrative the landscape is re-made and opened up to further interpretations. The content of the narrative may be laid upon individual homes, fences and ramps, or the foundations where a building had once been but has since been lost in time, forgotten, erased or gentrified. Cattle dips are identified on land titles because the arsenic used can contaminate the soil for decades after the dip use ceased. Cow bails have been converted to studios and the clearances are covered with the paspalum dilatatum grass that transformed the landscape and the agricultural economy. Pig meat consumption in Australia has increased but the pigpens situated below the bails have been converted to other uses as there is no skim milk flowing down from the milking. In the 2006 Australian Census, 877 people considered Koonorigan the place they most likely call home. The village is home to more people than ever lived here permanently in the past, but unlike then, there is no school, no local CWA and only a couple of dairy farms remain. Indeed, the majority of workers in Koonorigan now define themselves as professionals (Census

Reading a local landscape is no less fraught with difficulty than one less familiar. Any local landscape will be characterised by a diversity of uses and needs, which make it difficult to pin down. While the social history of a place is visible in its landscape, the meanings ascribed to that landscape may be multiple, and change over time. People, settings and meanings are not static in this sense, rather they are dynamic and evolve in terms of (often-reciprocal) changes in those individuals and their settings. Dairy farmers, for instance, look at the revegetation of old paddocks as 'rubbish', lamenting the proliferation of native plants and invasive weeks and decrying the waste of land that has no viable productive life. The new settlers who were able to buy the land they subdivided are also vocal about different aspects of life on the land. Agriculture is under pressure from competition for land from other uses, meaning there is potential for conflict between those people who merely want to live in a rural setting (like me) 
and those who want to make a living from it, although no such conflict currently exists locally. In a place like the north coast of NSW, where the movement of peoples, internal migration and settlement have characterised its history since European invasion, the meaning of the place varies between different groups, and these may be mobilised in arguments about the future as people struggle with movements for change around local food and food security, the environment and aesthetics. On the other hand, there is growing awareness of the importance of what Ross Gibson calls ways of knowing with country, that is, 'looking intently at a landscape we live in or value to see what it reveals of systems of wisdom and warning'. Gibson calls this political ecology, a way of knowing with country (not just knowing the land separated from ourselves), and suggests that this represents a more embodied connection to land (qtd. in Park 1995: 15).

In the past, regional variations in ecology, climate and culture contributed to preferences for and attitudes towards particular foods. This is also true today when distribution and transportation make almost everything available anytime. The identity of a region, to which its food contributes, is thus not only dictated by the availability of ingredients. How these are used and consumed is mediated by culture as much as geography and these have a reciprocal impact on each other. Food consumption plays a crucial role for the construction of local and national identities and the changing self-understanding of social groups, migrants and ethnic communities. A complicated story of alliances, food adventures, conservatism conflicts and accommodation is inscribed on the land. The gastronomic landscape of the north coast is a transnational one; created by tastes linked elsewhere, in a series of interconnecting cultures, ideas, histories and so on, which Doreen Massey argues construct places (1995: 13). Like other traditions, food does not have to be 'placebound'. The local farmers market, seen as the clearest indication of people's growing interest in local food, is itself ambiguous. This is because the farmers market represents both the epitome of local identity and the unsettling of that identity by the production, harvest and trade of imported foods (as well as native foods for export) that now define the tastescape of the north coast.

\section{Conclusion}

The Norco butter churn which now sits on the riverbank is a reminder of the importance of the dairy industry to the region and the value of the export market to the industry. It links the village of Koonorigan to both its neighbouring town and the rest of the world. The churn calls attention to the wharves opposite that brought cream to the factory that was once the largest butter producer in the state. The river was a defining feature of commercial life in Lismore and a shared site from which collective experiences of fishing, boating and so on were built, as well as the experience of swimming in dairy waste. But the river also prompts discussion about the nuances of daily experience; it was a force that shaped social life, cultural experience and interactions. Historically, it was an important feature of social life and the local economy. Likewise, the farms on which people lived did not alone provide a single shared interest that defined the community of Koonorigan. Rather, the occupation of 
dairying also created a community linked by shared interests and concerns. Their occupation has left an indelible print on the landscape and an impact on the environment that continues with other forms of cattle grazing. The traditional divide between production and consumption, however, has intensified with the industrialisation of agriculture and has alienated consumers from contemporary food production. Alternatives to the conventional food sector exist in local food movements and farmer's markets, but an alternative approach to research that considers tastescapes, shaped by both production and consumption is also important. Eating at home may provide a means of knowing with country if we understand how to read our actions.

Ann Vileisis reminds us that ' food isn't solely the means to a meal; it also provides a fundamental means for making sense of our place in the world' (2007: 52). The stories we associate with food and foodways become food narratives that inform culture, rather than just reflect it. This tastescape of Koonorigan gives expression to the way food produces, reproduces and transforms the land and culture. Food is fundamental to culture not just because we eat everyday, but also because it shapes the history of a place; ecological changes (with their attendant cultural transformations) that food choices, and not just production have engendered. In the $19^{\text {th }}$ century the term 'culture' did not refer to literature or ways of life. It was used as a verb to signify the use of wisdom and insight to foster living things. The culture of Koonorigan can still be read in the land and that culture is embedded in wider narratives that are simultaneously local and transnational.

\section{Endnotes}

1. In July 2010, the Australian National Health and Medical Research Council (NHMRC) was criticised when it released a draft report on a new 'Food Modelling System' which suggested caps on meat and fish intake on environmental grounds. An article in The Australian newspaper suggested that the NHMRC had subverted food science to fit a green agenda (21 July 2010). The CSIRO and the Heart Foundation were cited as being unhappy that the modelled diets had too little red meat and fish. According to nutritionist Rosemary Stanton, the modelling exercise limited red meat to $455 \mathrm{~g} / \mathrm{week}$, which is similar to the top end of the currently accepted Australian Guide to Healthy Eating's recommendation of 65-100g, 3-4 times a week. For fish and seafood, the modelling exercise used a weekly intake ranging from $100 \mathrm{~g}$ to $280 \mathrm{~g}$-well above current average consumption of about $70 \mathrm{~g} /$ week. As Stanton points out, though, the CSIRO's first Total Wellbeing Diet Book (linked with promotions from Meat and Livestock Australia) recommended very large quantities of fresh and processed red meat as well as large quantities of fish. (Crikey, 2010).

2. The housewives' associations campaigned to lift the quotas and bans throughout the 1960s. Mrs. Jones, for example, appeared in the Age newspaper, declaring that 'the right of a housewife to use margarine in preference to butter seems a small issue when measured against some of the loftier aspirations of democracy'. If Mrs Jones and tens of thousands of Australian housewives are denied 'this basic freedom of choice, then they are being denied the very essence of freedom. When legislation strikes at the freedom of the individual's choice of diet, it may be time to ask 'Is Australia a free country?', (Jones 1996), August 12, 1966. 


\section{Works cited}

2006 About New South Wales, Census records 2006 at http://about.nsw.gov.au/view/census/Koonorigan/B03 (accessed September 2010)

Australian Bureau of Agricultural and Resource Economics 2002 'Trend toward larger farms likely to continue' [media release], 11 July at http://www.abare.gov.au/pages/media/2002/11 July1\%20.htm (accessed 9 July 2010)

Australian Bureau of Statistics 2004 '1301.0-Year Book Australia, 2004 Dairy industry' at http://www.abs.gov.au/Ausstats/abs@.nsf/90a12181d877a6a6ca2568b5007b861c/b006a83a9127b0f5c a256dea00053965!OpenDocument (accessed 9 July 2010)

Barthes, R 1988 The semiotic challenge, trans. R. Howard, New York: Hill \& Wang

Berry, W 1990 What are people for? New York: North Point Press

Bell, D 2006 'Variations on the rural idyll', in Paul Cloke, Terry Marsden and Patrick Mooney (eds.) Handbook of rural studies, London: Sage, 149-60

Burnett, J 1989 Plenty and want: a social history of food in England from 1815 to the present day $3^{\text {rd }}$ ed., Abingdon: Routledge

Commoner, B 1971 The closing circle: nature, man, and technology. New York: Knopf

Croaky the Crikey health blog at http://blogs.crikey.com.au/croakey/2010/07/27/unpicking-the-ozsrecent-splash-on-nhmrcs-green-diet-push (accessed July 2010)

Dairying Australia website at http://www.dairyaustralia.com.au/Our-Dairy-Industry/Industry-

Statistics/Butter.aspx (accessed 9 July 2010)

Falk, P 1994 The consuming body, London: Sage

Geertz, C 1977 The interpretation of cultures, New York: Basic Books

Gibson, C 2002 'Migration, music and social relations on the NSW far north coast' Transformations 2 (March) at http://www.cqu.edu.au/transformations (accessed 9 July 2010)

Gorman-Murray, A, K Darian-Smith and C Gibson 2009 'Scaling the rural: reflections on rural cultural studies' Australian humanities review 45, 37-52

Hall, S and J Henderson (eds.) 1976 Resistance through rituals, London: Hutchinson

Holloway, L, M Kneafsey, L Venn, R Cox, E Dowler \& H Tuomainen 2007 'Beyond the 'alternative''conventional' divide?: thinking differently about food production-consumption relationships', in D Maye, L Holloway \& M Kneafsey (eds.) Alternative food geographies, Oxford: Elsevier

Hoskins, WG 1955 The making of the English Landscape, London: Hodder \& Stoughton

Lupton, D 1996 Food, the body and the self, London: Sage Publications

Massey, D 1995 'Places and their pasts', History workshop journal 39, 182-92

Mink, N 'It begins in the Belly’ Environmental history 14 (April 2009), 312-22

Park, G 1995 Ngâ uruora The groves of life: ecology and history in a New Zealand landscape, Wellington: Victoria University Press

Petrini, C 2001 Slow food: the case for taste trans. William McCuaig, New York: Columbia UP

Petrini, C, Padovani, G 2005 Slow food revolution: a new culture for eating and living, New York: Rizzoli

Pollan, M 2006 Omnivore's dilemma: a natural history of four meals, New York: Penguin

Trubek, A 2005 'Place matters' in Carolyn Korsmeyer (ed.) The taste culture reader, Oxford: Berg, 260-70

Turvey, N 2006 Terania Creek: rainforest wars, Carindale: Glasshouse Books 
Vileisis, A 2007 Kitchen literacy: how we lost knowledge of where food comes from and why we need to get it back, Washinton DC: Island Press

Wadham, S \& GL Wood 1950 Land utilization in Australia $2^{\text {nd }}$ ed. Melbourne: Melbourne UP

Wessell, A 2008 'Public spaces and personal memories: working with students in the community' Oral history association of Australia journal 2: 30

Wilson, H (ed.) 2003 Belonging in the rainbow region: cultural perspectives on the NSW north coast, Lismore: Southern Cross UP 